\title{
THE ANALYSIS OF COOPERATIVE PRINCIPLE IN CORBUZIER PODCAST OF SITI FADILAH, SEBUAH KONSPIRASI - SAYA DIKORBANKAN EPISODE
}

\author{
Natalia Anggrarini ${ }^{1}$, Deuis Dian Rosdiana ${ }^{2}$ \\ Universitas Wiralodra, Jln.Ir.H. Juanda Km 3, Indramayu, natalia.anggrarini@unwir.ac.id, \\ deuis.dr@gmail.com
}

Diterima 27 Juli 2020, disetujui 05 Oktober 2020, diterbitkan 30 Oktober 2020

Pengutipan: Anggrarini, N \& Rosdiana, D.D. (2020). The Analysis of Cooperative Principle in Corbuzier Podcast of Siti Fadilah, Sebuah Konspirasi - Saya Dikorbankan Episode. Gema Wiralodra, Vol 11, No 2, Hal 292-310, Oktober 2020

\begin{abstract}
ABSTRAK
Discussing the misleading of information in interaction in Podcast is rare in language research. Considering the concept of cooperative principle and the failure of observing maxims in an interaction by Grice (1989[1967]), this research investigated the flouting and violating of maxims appears within the podcast. The data source of study is a podcast of Deddy Corbuzier with Siti Fadilah Supari, the Former of Indonesian Health Minister which entitled Siti Fadilah, Sebuah Konspirasi - Saya dikorbankan. This study discovers the participant's failing to observe the maxims, in form of flouting and violating. There are 57 exchanges flouted as the most common participant's failure in observing the maxims, which consists of 29 quantity maxims (50\%), 14 manner maxims (25\%), 9 quality maxims (16\%), and 5 relation maxims $(9 \%)$. Then it is followed by the violation in 7 exchanges, which occurs in 3 quality maxims (43\%), 2 quantity maxims (29\%), 1 relation maxim (14\%) and 1 manner maxim (14\%). The study finds the podcast provides the various information, since the participant provides the more contribution rather than is required as the domination of flouting in quantity maxim. This study implies the need of reconfirming of the utterance that is presumable to lead failure of information understanding.
\end{abstract}

Keywords: Grice, cooperative principle, flouting the maxim, violating the maxim

\section{INTRODUCTION}

Podcast currently is a new trend in talkshow entertainment. The communication occur in podcast runs like two or more people talk directly. It goes continuously throughout the participants in the podcast itself. As we know that communication is a continuous process in which the participants cooperate with each other by maintaining certain rules and regulations in order to build the interaction. One of common interaction conducted is a conversation, which carries out a reciprocal act. For the most part, the conversation incorporates topic nomination, turn-taking, negotiation of meaning, etc. (Markee \& Kasper, 2004). The effective conversation occurs when the participants give the appropriate contribution in talk exchange.

The appropriate contribution during the communication is discussed in Grice's (1989[1967]) theory about a concept of conversation and the other forms 
of language, which called as the cooperative principle. The cooperative principle explains the process of how conversation occurs in the appropriate stage by developing a common set of purposes. It is constructed by four subprinciples of maxims, which involve quantity, quality, relation, and manner. In other words, the successful conversation may occur when people follow the cooperative principle.

However, there is a condition which make people fail to observe the maxims and it will influence the meaning brought in the conversation. According to Grice, flouting and violating are the most frequently used failure that occur in conversation every day (Agustina and Ariyanti: 2016). Sholikhah (2018) support that the failure in understanding the meaning in conversation often happens due to the less of observation of the participants for the utterance. It is also happens in conversation that occur through the media (Kurniati and Hanidar, 2018). Cutting (2002) explains that the flouting occurs when the speaker fails in observing the maxims but still expecting the listeners to recognize the implied meaning of utterance. Meanwhile, the violating occurs in order to mislead the listeners which distract them for the current purpose of the exchange. It means that based on the concept of the cooperative principle and its failure of observing maxims, there will be explored the meaning of utterances delivered in conversation.

One of interaction's language form which carries out the conversation is a podcast. Podcast is a series of digital video or audio broadcast that can be downloaded and played on mobile devices. It utilizes the voice which is the most influential tool that relates to audience very quickly. Lately podcast becomes a very popular media to share the information to public. Following that, one of podcasts that gets the public interest nowadays is coming from Deddy Corbuzier who produces a podcast entitled Siti Fadilah, Sebuah Konspirasi - Saya dikorbankan in his YouTube channel. This podcast has gotten the million views on Indonesian YouTube which proves the high response of public. It is because the content of podcast talks about Covid19, which is still the striking topic in society. Moreover, the content is associated with the current issue of Covid19 related to its conspiracy. Then, the podcast is attractive due to the interviewee, Siti Fadilah Supari as the Former of Health Ministry of Indonesia. However, there are four main points brought in this podcast, which involve; criticizing the vaccine 
and pandemic phenomenon related with Bill Gates, the reformation of WHO, the current condition of pandemic in Indonesia, and the suggestion for Indonesia to combat Covid19. In addition, it takes more attention since Direktorat Jenderal Pemasyarakatan from the Law and Human Rights Ministry perceives this podcast is illegal to publish. In short, this podcast is very controversial started from the content, the interviewee and the production itself. These conditions then encourage the writer to analyze this podcast by utilizing the cooperative principle theory of Grice (1989[1967]). Following that, the flouting and violating of maxims within the utterances will be examined. Thus, the meaning brought the conversation in a podcast will be discussed based on how the participants observe the maxims.

There are some researches conducted to analyze the cooperative principle. First, Diningrum and Musyahada (2016) find the participants flout the maxim of relation often because they want to provide an opinion, jokes and give further information. Second, Nur (2018) discovers the dominant violation occurs is the maxims of quantity. Third, Toda and Ghozali (2017) identify the maxim of quality as the highest maxim violated by the participants and they do it as an effort to hide the truth in interaction.

Most recent researches only analyze one type of the failure of observing maxims. While there is a need to find out what kind of failure that mostly happen among paricipants in Podcast. When the participants fail to observe the maxims, the further meaning implied within the utterances does not get much explanation. It means that there is an empty space of information that should be further explained. To fill this gap, the current study attempts to add the others type of failure of observing maxims which focuses on the flouting and violating. In addition, this research provides the implicature within the utterance. Thus, there will be more exploration to find the meaning and information in the podcast.

In accordance with the explanation above, this current study analyzes the cooperative principle in a podcast that provides interaction between Deddy Corbuzier and Siti Fadilah Supari, the Former of Indonesian Health Minister. It is interesting to analyze this podcast because it talks about the current issue, the Covid19 and gain much attention from public. On account of the necessary of 
finding and discussion, thus this research has purpose to describe the meaning of utterances by considering the flouting and violating of maxims appears within the podcast.

\section{LITERATURE REVIEW}

\section{The Cooperative Principle}

Cooperative principle is a concept introduced by Grice (1989[1967]) which explains the cooperative interaction of two parties in a conversation and the other forms of language to develop a common set of purposes. In other words, the cooperative principle guides people to communicate something in proper contribution so there will be a meaningful conversation. In the conversation it is important to set that the communication run for what is said and what is meant (Chen, 1996). Grice (1989[1967]) further mentions that people should observe the certain principle to participate in an interaction. People should make their contribution such as is required, at the stage at which it occurs, by the accepted purpose or direction of the talk exchange in which they are engaged (Grice, 1989[1967]: 26).

The principle above explains that it is necessary for people to provide the sufficient information based on the needs in an interaction. Following that, people should realize the particular area involving the participant, the setting, the culture and the others to support their right contribution. Then, people should consider the orientation of interaction which becomes the topic of the talk, so it will guide to share the required information. In other words, what the cooperative principle explains is that people who are involved in a conversation are working on the assumption that the certain rules control their operation.

Grice (1989[1967]) describes the cooperative principle into four subprinciples which are called as maxims. First is maxim of quantity, which associated with the amount of information. In this maxim, people should realize the current purposes of the exchange so they will produce the required contribution based on the needed information. Second is maxim of quality, which guides people to be sincere and believe about what they utter. It means that people should not say something that they do not believe to be true or for which they lack adequate evidence when they make the utterance. Third is maxim of relation, 
which requires the information should be relevant with the topic of conversation. It means that people should give the relevant utterance related to the exchange. Fourth is maxim of manner, which associated with the regularity of information. This maxim requires people to avoid the obscurity and ambiguity of expression in their utterance. After that, the utterance should be delivered in brief and orderly. It means that people should avoid the unnecessary prolixity or verbosity of utterance.

\section{Flouting the Maxims}

There is a condition which make people failed to observe the maxims. It means that there is a disobedient towards the maxims. According to Grice, one of ways of failing to observe the maxims is flouting (Thomas: 1995). The flouting happens when people deliberately and ostentatiously contravenes a maxim. Levinson (1983) specifies the maxims are flouted because it may persuade the listeners to infer the hidden meaning behind the utterances. It means that the speaker employs implicature to the listeners. When the speaker flouts the maxims, she/ he does not give the right information as required by maxims. However, the listeners still can reach the meaning due to the implicature.

Flouting can happen in all maxims. First is flouting the maxim of quantity, which happens when the speaker gives too little or much information than the situation requires. Second is flouting the maxim of quality, which happens when the speaker produces an utterance that cannot be interpreted in literal. Then this utterance should be inferred by the listeners to uncover the meaning according to the context. Third is flouting the maxim of relation, which tends to occur when the response is obviously irrelevant to the topic. In this case, the speaker has an abrupt change of topic which fails the interlocutor's purpose in asking the question obviously. However, the speaker still expects the listeners to realize the meaning by making connection between current topic and the preceding one. Fourth is flouting the maxim of manner, which occurs when the speaker uses the obscure language such as the ambiguity, the prolixity, and the verbosity. This condition creates an implicature which makes the listeners should look for an additional set of meanings 


\section{Violating the Maxims}

Grice mentions the other ways of failing to observe the maxims refers to violating (Thomas: 1995). Violating the maxim occurs when people in a conversation fails to observe one or more maxims with the intention to deceive the listeners. Moreover, they often use an implicature with the intention to mislead or to achieve some other purposes. Flowerdew (2013) further explains the speaker may not tell the truth at all in case of violating the maxims. In such case, she/ he disregards the cooperative principle without indicating the listeners that they are doing so.

According to Cutting (2002), violating may occur in four subprinciples of maxim. First, violating towards the maxim of quantity, which indicated when the speaker does not give enough information to the listeners about the whole picture or the topic being discussed. Second violating towards maxim of quality, which associated with the wrong information provided by the speaker and it can be said as lie. Third violating towards the maxim of relation, which occurs when the speaker changes the topic to avoid the answer or topic that brought by other interlocutors in conversation. Fourth violating towards the maxim of manner, which associated with the obscure and vague utterance to avoid a brief and orderly answer in a conversation.

The failure toward the maxims between violating and flouting is differed based on the speaker's intention. In flouting the maxim, the speaker has intention to guide the listeners infer the hide meaning from the broken maxims. In other side, the speaker tries to mislead the listeners in violating the maxims. So, the listeners will be distracted for the current purpose of the exchange.

\section{Implicature}

In the case of conversation and other forms of language, the utterance used do not always carry the literal meaning. According to Grice, there is non-literal meaning which must be inferred from the context and the cooperative principle (Flowerdew: 2013). This non-literal meaning belongs to a special type of inference which called as implicature. Implicature learns about how to understand implied meaning within the utterance. Implicature occurs when the speaker hides 
a meaning in an utterance and expects the implied meaning reached by the listeners.

This research focuses on the conversational implicature because it relates to the context of situation and the cooperative principle. Conversational implicature appears when people speak with additional meaning. Anggrarini (2017) further explains the function and inferences within the utterance are necessary to interpret the meaning in case of conversational implicature. It means that the listeners should recognize the context and the words directed to the implicature in understanding what a speaker utters.

Grice states that it is a must for listeners to rely on the following information, so they will work out on a conversational implicature (Flowerdew: 2013)

1) the conventional meaning of the words used, together with the identity of any references that may be involved;

2) the $\mathrm{CP}$ and its maxim;

3) the context, linguistic or otherwise;

4) other items of background knowledge;

5) mutual awareness of 1-4.

\section{RESEARCH METHOD}

The study belongs to a qualitative content analysis because it analyzes the use of language as communication with attention to the content or contextual meaning of the text. (Budd, Thorp, \& Donohew, 1967; Lindkvist, 1981; McTavish $\&$ Pirro, 1990; Tesch, 1990). The writer utilizes the theory of the cooperative principle conveyed by Grice (1989[1967]). Accordingly, this study has purpose to describe the meaning of utterances by considering the application of cooperative principle related to the maxims flouts and maxims violation found within the podcast.

The data source is a podcast of Deddy Corbuzier in Close the Door series for the episode of Siti Fadilah, Sebuah Konspirasi - Saya dikorbankan (Exlcusive). The podcast video is downloaded from https://youtu.be/by3SglhT9Dc. Besides download the video, the writer transcribes the utterances in written form to help the process of analysis. 
To conduct the research, there are three phases applied. First, collect the data or observation by watching the podcast video and transcribing the utterances in written form. Second, identify the categories of maxims, which involve the flouting and the violating within the podcast. Third, analyze and interpret the data by using the cooperative principle theory from Grice (1989[1967]).

\section{FINDING AND DISCUSSION}

\section{Finding}

The cooperative principle analysis at corbuzier podcast of Siti Fadilah, Sebuah Konspirasi - Saya dikorbankan episode is conducted by focusing on the participants' failure in observing the maxims. The failure types of observing the maxims in this podcast refer to the flouting and violating. The analysis process reveals that the podcast contains the more flouting rather than the violating of maxims. The result identifies 57 exchanges contained the flouting of maxims and 7 exchanges for the violating of maxims. The flouting and violating break each maxims of cooperative principle, which involves quantity, quality, relation, and manner. The further results are provided into the following table below.

Table 1. the Summary of Flouting the Maxims

\begin{tabular}{lcc}
\hline \multicolumn{1}{c}{ Flouting the Maxims } & Frequency & Percentage \\
\hline Quantity & 29 & $50 \%$ \\
\hline Manner & 14 & $25 \%$ \\
\hline Quality & 9 & $16 \%$ \\
\hline Relation & 5 & $9 \%$ \\
\hline Total & $\mathbf{5 7}$ & $\mathbf{1 0 0} \%$ \\
\hline
\end{tabular}

The dominant flouting in a podcast belongs to the maxim of quantity which occurs 29 times or $50 \%$. The most frequently flouting the maxims of quantity happens because they provide more contribution than the required one. Therefore, this podcast contains the various information indeed.

Table 2. the Summary of Violating the Maxims

\begin{tabular}{|c|c|c|}
\hline Violating the Maxims & Frequency & Percentage \\
\hline Quality & 3 & $43 \%$ \\
\hline Quantity & 2 & $29 \%$ \\
\hline Relation & 1 & $14 \%$ \\
\hline Manner & 1 & $14 \%$ \\
\hline Total & 7 & $100 \%$ \\
\hline
\end{tabular}


In other side, the violating within the podcast is dominated in the maxim of quality, which occurs for three times or $43 \%$. However, there is a contradictive situation. Even the various information provided in a podcast, the maxim of quality violation indicates that there are such points that hidden and neglected by the participants.

\section{Discussion}

\section{Flouting}

The podcast of Deddy Corbuzier and Siti Fadilah as the Former of Indonesian Health Minister performs 57 flouting the maxims. In this analysis, the flouting is dominated in the quantity maxim with $50 \%$. Then it is followed by the manner maxim in $25 \%$, the quality maxim in $16 \%$ and the relation maxim in $9 \%$. The detail explanation of each flouting is presented into following discussion.

Flouting of Quantity Maxim

There are 29 exchanges flouted in this podcast, which make the quantity maxim as the most common flouts. This is provided the example of flouts as follow:

Ir : Kalau Ibu mengatakan, bahwa Ibu pada saat itu dipenjara akhirnya karena sebuah tuduhan korupsi. Artinya kan semua yang Ibu katakan itu mengandung resiko. Artinya Ibu dijebloskan karena sesuatu sebenarnya. Itu yang Ibu percaya?

I : Ya menurut saya. Saya mempunyai suatu sikap yang sikap itu mengakibatkan saya dipenjara. Tapi saya tidak menyesal, karena sikap saya untuk melindungi rakyat saya. Saya berbuat itu adalah bukan untuk saya. Saya dapet apa? Kan saya engga dapet apa-apa dari yang saya lakuin. Tapi saya yakin, saya melindungi rakyat saya. Dan ternyata bukan Indonesia saja yang terlindung, ternyata pandemi itu gagal. Kalau dihitung itu berapa ribu triliyun kerugian. Sekarang hitung saja dengan Corona sekarang berapa ribu triliyun kerugian seluruh dunia. Apalagi kalau flu burung. Lah yang saya terkesan sampai sekarang, lah wong tidak menular ko WHO berani bilang menular.

This part is started when Deddy tries to conclude the information Siti Fadilah shares previously. He asks her confirmation that she is prisoned because of the 
accused corruption case, which means what actually she shares in a podcast contains the risk. Following that, Siti Fadilah presents the sufficient information by saying it clearly in Ya menurut saya. Saya mempunyai suatu sikap yang sikap itu mengakibatkan saya dipenjara. In short, she confirms the statement uttered to her. But she adds the other contribution by providing the furter explanation in Tapi saya tidak menyesal, karena sikap saya untuk melindungi rakyat saya. Saya berbuat itu adalah bukan untuk saya. Saya dapet apa? Kan saya engga dapet apa-apa dari yang saya lakuin. Tapi saya yakin, saya melindungi rakyat saya. Dan ternyata bukan Indonesia saja yang terlindung, ternyata pandemi itu gagal. Kalau dihitung itu berapa ribu triliyun kerugian. In this case, she asserts that she is prisoned because she has taken crucial decision. She also explains that she does not regret for taking the decision because it is for the society importance. Then it is continued by the impact happened and the possibility if the decision was not taken at that time. So, it provides more informative answer. According to Grice (1989[1967]), the quantity maxim associated with the amount of information. Since Siti Fadilah gives much information than the situation requires, it is considered as the flouting here.

However, there is an implicature appeared, which indicated by sikap. In this case, Siti Fadilah guides the listeners to infer what actually she has done until she is prisoned. It can be revealed by paying the attention to the content of this podcast. In addition, this implicature can be identified by the listeners by underlining what Siti Fadilah mentions at the end, Lah yang saya terkesan sampai sekarang, lah wong tidak menular ko WHO berani bilang menular. It means sikap that she mentions before related with the decision of WHO that acknowledges that H5N1 virus is human to human transmission. In other words, sikap mentioned by Siti Fadilah can be an inference to realize the meaning of the whole utterance here. As mentioned by Anggrarini (2017) the inference within the utterance is important to interpret the meaning in case of conversational implicature. Thus, based on Siti Fadilah believes, she is prisoned because she has made the decision for being vocal to announce the different perception about the transmission of H5N1 virus at that time. Then, she is very brave to do that since it relates with the society importance. 
Flouting of Manner Maxim

There are 14 parts found as the flouting of manner maxim. One of the examples is presented below:

(C18)

Ir : Kalau China korban, Amerika juga korban. Berarti ada kelompok yang membuat?

I : Kemungkinan menurut saya itu perkiraan saya belum tentu betul belum tentu benar belum tentu salah belum tentu benar.

This exchange shows that Siti Fadilah has intention to assert what she has said about the certain circle behind the Covid19 virus development is not totally valid by saying ... Kemungkinan ... Hence, she provides information that lacks adequate evidence, which means the flouting of quality maxim. In addition, she says menurut saya itu perkiraan saya which confirms that it does not guarantee the accuracy. However, she mentions it in prolixity by saying itu belum tentu betul belum tentu benar belum tentu salah belum tentu benar. It means that she flouts the maxim of manner. As mentioned by Grice (1989[1967]), the utterance should be delivered in brief and orderly to follow the maxim of manner. In this case, she presents the prolixity to deliver the maning. This actually will make the listeners curious to find the accurate information. Therefore, it guides the listeners to pay more attention to the things discussed in the podcast.

Flouting of Quality Maxim

The flouting of quality maxims occurs nine time in the podcast. The following example is presented below:

Ir : Tapi, pada saat pertama kali Ibu dijebloskan ke penjara. Apakah Ibu tidak emosi, tidak marah? Kalau ibu merasa tidak salah pada saat itu.

I : Ya pastilah itu manusiawi. Tapi saya tahu, musuh saya besar jadi saya kalah. Saya bukan salah tapi saya kalah. Tapi saya pernah menang. Kalau dulu saya pernah dibilang Pak Karni Ilyas, dulu belum ada ILC tapi dia wawancara begini, lebih baik jadi harimau satu hari daripada jadi kambing seumur hidup. 
Levinson (1983) mentions that the maxims are flouted because it may persuade the listeners to infer the hidden meaning behind the utterances. It means that the speaker employs implicature to the listeners. When the speaker flouts the maxims, she/ he does not give the right information as required by maxims. However, the listeners still can reach the meaning due to the implicature. For this example, it is clearly to say that harimau and kambing does not have the literal meaning for this exchange, as they are animal. In this case, Siti Fadilah utilizes the metaphor of animal; harimau and kambing to represent her identity related what she has done previously. Hence, it is considered as the flouting of quality maxim. According to Grice (1989[1967]), flouting of the maxim of quality happens when the speaker produces an utterance that cannot be interpreted in literal. Then this utterance should be inferred by the listeners to uncover the meaning according to the context. In this case, the implicature is derived from harimau and kambing, and the context relates to the accused corruption case of Siti Fadilah.

Considering the implicature brought in harimau and kambing, Siti Fadilah presents the indicators to listeners in ... Saya bukan salah tapi saya kalah. Tapi saya pernah menang ... In this case, she asserts that she has not corrupted or she has not done mistakes. Moreover, she ever won, which refers to failing the pandemic status of $\mathrm{H} 5 \mathrm{~N} 1$ virus. Based on these points, actually, harimau represents a person who has strong orientation and courage to prove what she/ he believes. It is suitable to what Siti Fadilah did when she is very vocal to disagree the claim of $\mathrm{WHO}$ for $\mathrm{H} 5 \mathrm{~N} 1$ human to human transmission. Then kambing represents a person who only follows the provided rule without any consideration. It means Siti Fadilah is prisoned, which make her should achieve the present condition for today.

Flouting of Relation Maxim

The relation maxim become the less common flouting found in the podcast, which only occur five times or $9 \%$. The example of flouting is presented as follow:

Ir $\quad$ : Jadi artinya pengetesan kita masih tanda tanya? 
I : He'em. Ya, kurang pas lah, kurang tepat. Tepatnya kalau pakai alat kita sendiri, yang berbasis virus kita sendiri. Kita banyak ahli, kita pinter-pinter cuman kita butuh dana. Fokuskan dana untuk research itu karena selama ini research selalu mendapatkan dana yang kecil. Kemudian mengharapkan bantuan dari asing. Bantuan dari asing itu menggetarkan, menggoyahkan hati untuk nasionalismenya juga bergoyah. Karena wong ya yang perhatian malah orang asing, malah yang ngasih dana orang asing, lama-lama dia lupa mana induknya mana semangnya. Nah ini Indonesia itu research masih terlalu kecil, padahal itu penting sekali.

The required information for this exchange is a confirmation about the less accurate of Indonesian test for Covid19. Siti Fadilah acknowledges it. But she further explains the Indonesian research condition that gets the low budget allocation. It is obviously the irrelevant answer to the purpose of exchange. Furthermore, she states the foreign funds is accountable for the nationalism, which indicates the different topic talking about. Thus, it is considered as the flouting of relation maxim. As mentioned by Grice (1989[1967]), the flouting of relation maxim is indicated when the speaker has an abrupt change of topic which fails the interlocutor's purpose in asking the question obviously. However, the speaker still expects the listeners to realize the meaning by making connection between current topic and the preceding one. In this case, the topic refers to the accuracy of Indonesian test for Covid19, and it changes to the Indonesian research field.

Since Siti Fadilah presents the irrelevant information, there is another purpose implied from this utterance, .... Kemudian mengharapkan bantuan dari asing. Bantuan dari asing itu menggetarkan, menggoyahkan hati untuk nasionalismenya juga bergoyah .... Actually, nasionalisme is the inference to reveal the implicature itself. Nasionalisme is often associated with the belief of nation to support each other in building the country. But the different condition appears in Indonesia nowadays, when the foreign fund becomes a common policy in such fields, including the research practice. In this case, she underlines that government does not give sufficient support to the research field, since it only receives the low budget allocation. Thus, nasionalisme here is questionable. However, she has 
intention to make the listeners realize that research field needs more support from government. Following that it can be suggestion to the government itself. This condition confirms Anggrarini (2017) who states that an inference within the utterance is useful to interpret the meaning. It means that when the listeners recognize the words directed to the implicature, or in this case is nasionalisme; they will understand what Siti Fadilah actually utters.

\section{Violating}

The violating of maxims in a podcast of Deddy Corbuzier and Siti Fadilah as the Former of Indonesian Health Minister occurs only 7 times. The most common violated is quality maxim for 3 times or $43 \%$. After that it is continued by the quantity maxim in $29 \%$, the relation and the manner maxim in $14 \%$. The following discussion reveals the further explanation of each violating.

\section{$2.1 \quad$ Violating of Quality Maxim}

The most common violation found in a podcast is maxim of quality which occurs three times. This is the following example of violation:

Ir $\quad$ : $\quad$ Tapi kenapa Ibu masih berani bicara sekarang? Kan saya baca di media-media, Ibu masih berani bicara tentang virus ini, Ibu berani berbicara tentang apa yang ibu lakukan, bahkan ada media yang mengatakan Ibu dilindungi sniper. Dan itu ada di media loh bu.

I : : Oh ya? saya tidak ngomong tentang itu. Saya ngomong ilmu yang orang banyak harus tahu. Jangan sampai rakyat ini engga tahu sama sekali. Jadi saya hanya menyampaikan suatu ilmu pengetahuan. Dan itu menurut saya wajib. Kalau saya tahu sesuatu yang tidak baik, saya diam saja, padahal saya tahu, saya diam saja, itu dosa.

This conversation shows that Deddy asks Siti Fadilah about the reason behind her braveness for being vocal to the Covid19 pandemic condition. Then, she begins the answer by saying, Oh ya? saya tidak ngomong tentang itu. It means that she refuses the claim of her vocal action. However, it becomes the contradiction, since she has delivered various infromation, which involves $\mathrm{H} 5 \mathrm{~N} 1$, Covid19, the case of her accused coruption, and even Bill Gates. According to 
Cutting (2002) violating towards the maxim of quality associated with the wrong information provided by the speaker. In this case, Siti Fadilah is considered violating the quality maxim because she avoids to confirm her vocal action which actually has been revealed from the information that she shares previously.

Violating of Quantity Maxim

There are two exchanges violated by the interviewee. Thus, the violating of quantity maxim represents $29 \%$. This is the example of exchanges contained the violating:

Ir : Di seluruh dunia, tempat pembuatan vaksin disupport oleh Bill Gates berarti bu? Jadi Ibu mencurigai bahwa ini adalah buatan dia?

I : Saya tidak mencurigai tapi orang bisa berfikir sendiri. Ngapain sih? Kalau semua orang anda support, itu kan artinya supaya nurut ya sama kita. Atau at least menghormati yang nyupport dong. Tadinya engga ada yang nyupport, terus tiba-tiba dia dengan sangat dermawan, beliau kan filantropis. Yang penting Indonesia harus mandiri, harus bisa bikin vaksin sendiri, bisa bikin rapid test sendiri, bisa bikin swab test sendiri, bisa bikin primere sendiri.

Grice (1989[1967]) mentions the maxim of quantity requires people to realize the current purpose of the exchange so they will produce the required contribution based on the needed information. In the $\mathrm{C} 22$ conversation, the needed information is about the confirmation whether Siti Fadilah distrusts Bill Gates or not. However, she provides more information here, such as the description of society when receive the support, the Bill Gates' role as filantropis, and the importance of Indonesia for being independent to combat the Covid19. In this case, she suddenly moves to another topic by saying Yang penting Indonesia harus mandiri, harus bisa bikin vaccine sendiri, bisa bikin rapid test sendiri, bisa bikin swab test sendiri, bisa bikin premiere sendiri. That different topic uttered to guide the listeners focus only for the issue in Indonesia. In addition, she seems like avoid discussing more about Bill Gates. It means that, Siti Fadilah violates the maxim of quantity by providing the more unrequired information to distract the focus of the listeners. 
Violating of Relation Maxim

The violating of relation maxim found only once, which has the percentage of $14 \%$ for this podcast. The following exchange is indicated as the part when the interviewee fails to observe the maxim of relation.

(C22)

Ir : Di seluruh dunia, tempat pembuatan vaksin disupport oleh Bill Gates berarti bu? Jadi Ibu mencurigai bahwa ini adalah buatan dia?

I : Yang penting Indonesia harus mandiri, harus bisa bikin vaksin sendiri, bisa bikin rapid test sendiri, bisa bikin swab test sendiri, bisa bikin primere sendiri.

Deddy restates Siti Fadilah's utterance which mentions that the whole company of vaccine production in the world is supported by Bill Gates. Then he concludes it as the distrust of her to Bill Gates. Thus, he asks to confirm it. Following that, Siti Fadilah answers it. Actually, at the beginning, her answer is still relevant to the question, even it violates the quality and quantity maxim as discussed before. However, she presents the irrelevant point by suddenly saying Yang penting Indonesia harus mandiri, harus bisa bikin vaccine sendiri, bisa bikin rapid test sendiri, bisa bikin swab test sendiri, bisa bikin premiere sendiri. It has no relevance with the required information that questioning her distrust to Bill Gates. This utterance literally indicates that Siti Fadilah changes the topic to avoid discussing deeper about Bill Gates. Thus, she guides the listeners to focus only what is happening in Indonesia. In other words, she has the intention to achieve the other purpose. This condition is in line with Cutting (2002) who mentions that violating towards the maxim of relation occurs when the speaker changes the topic to avoid the answer or topic that brought by other interlocutors in conversation. In addition, the violation is conducted smoothly by presenting first the other answer relates to the question. As mentioned by Flowerdew (2013) that in such case, the speaker disregards the cooperative principle without indicating the listeners that they are doing so. 
Violating of Manner Maxim

The other violation occurs only one time at the podcast is the maxim of manner. Thus, the percentage here belongs to $14 \%$. The violating of manner maxim found in this following exchange:

(C12)

Ir : : Artinya flu burungnya hilang sendiri?

I : Kalau di ekonomis, saya dikatakan, saya adalah menyelesaikan pandemi flu burung dengan transparansi.

Siti Fadilah is asked the confirmation about how the H5N1 virus development ends. In this case, she provides the answer that lacks the adequate evidence, which means violating the quality maxim. It is because she avoids answering that the H5N1 virus development is lost by itself and prefers mentions the accomplishment for $\mathrm{H} 5 \mathrm{~N} 1$ based on economic field. This condition also relates to how she presents the answer. She has the ambiguity expression by mentioning ekonomis and transparansi, which do not have the further explanation within the utterance. In this case, ekonomis and transparansi become the implicature should be recognized by the listeners. In Kamus Besar Bahasa Indonesia, ekonomis means being careful to spend money, use of goods, language, time; not wasteful; thrifty and it is categorized as adjective. But she mentions di first as the adverb, so the meaning may be confusing. Then, transparasi associated with the real and clear state. Thus, it represents that she is very vocal to combat the H5N1 virus. However, the listeners should relate what actually it means with the economic side since she has mentioned the politic field in the previous utterance. In this case, these two words actually may break the focus of listeners. As mentioned by Cutting (2002), violating occurs to mislead the listeners which distract them for the current purpose of the exchange. Thus, the listeners do not find the clear confirmation about how the H5N1 virus development end.

\section{CONCLUSION}

Based on the discussion above, the podcast of Deddy Corbuzier and Siti Fadilah Supari, the Former of Indonesian Health Minister contains the flouting and violating, which found in the four subprinciples of the cooperative principle; 
quantity, quality, relation and manner maxim. The flouting becomes the most common failure of observing the cooperative principle with 57 exchanges and it is followed by violating with 7 exchanges. The researcher concludes that flouting and violating occur to commit the other purposes. Following that, these purposes are carried out through the implicature within the utterance. In some exchanges, the implicature presented when Siti Fadilah flouts or violates more than one maxim at the same time. In other words, the failure of observing some maxims related one to another to build a meaning in this podcast. The main meaning of this podcast actually is to provide the various information such as the accused corruption of Siti Fadilah, her vocal action in case of H5N1 virus, the Covid19 virus development and its vaccine production. It is because the flouting of quantity maxim dominates the failure of observing the cooperative principle in a podcast, as the more informative contribution presented than is required. This study implies that the important of observation to avoid failure of understanding the utterance is needed. Whether it is direct communication or communication through media in this case podcast. Observing the utterance is needed to be taken carefully to avoide the failure that leads to ignoring the maxim.

\section{REFERENCES}

Anggrarini, N. (2017). Conversational Implicature Analysis of Text Message Between Native Speaker and Foreign Language Speaker of English. Wiralodra English Journal, 1 (1).

Agustina \& Ariyanti. (2016). Flouting Maxim to Create Humor in Move This Means War. Language Horion, 4 (2), 38-45.

Budd, R. W., Thorp, R. K., \& Donohew, L. (1967). Content Analysis of Communications. New York: Macmillan.

Chen, Rong. (1996). Conversational Implicature and Characterisation in Reginald Rose's Twelve Angry Men. Language and Literature Vol 5 No 1. Sage Journal.

Cutting, J. (2002). Pragmatics and Discourse: A Resource Book for Students. New York: Routledge. 
Diningrum, A \& Musyahda, L. (2016). Conversational Implicature in "Sarah Sechan" Talk Show of Go Green Episodes. Universitas Airlangga. Anglicist, 05 (1).

Flowerdew, J. (2013). Discourse in English Language Education. New York: Routledge Taylor and Francis Group.

Grice, H. P. (1989 [1967]). Logic and conversation. In Grice, H. P. (Ed.) Studies in the Way of Words (pp. 22-40). Cambridge, MA: Harvard University Press.

Kurniati, M., and Hanidar, S. (2018). The Flouting of Gricean Maxims in the Movies Insidious and Insidious 2. Lexicon Vol.5 No. 1. Indonesia. Universitas Gadjah Mada.

Levinson, S. C. (1983). Pragmatics. Australia: Cambridge University Press.

Nur, M. U. (2018). Violation of Grice's Cooperative Principle on the Dialogue of "The Wild Duck" by Henrik Ibsen. Journal of Research on Applied Linguistics Language and Language Teaching, 2 (1).

N. Markee, and G. Kasper. (2004). Classroom talks: An introduction. Modern Language Journal, 88: 491-500.

Sholikhah, D. I., (2018). Flouting Grice's Maxim in Jane Eyre Novel by Charlotte Bronte. State Islamic University Sunan Kalijaga: Yogyakarta

Toda, M.A., \& Ghozali, I. (2017). Violations of Maxims Analysis of Cooperative Principle in Maleficent Movie. 